\title{
Flexible Working Arrangements, Work Life Balance and Women in Malaysia
}

\author{
A. Geetha Subramaniam, B. John Overton, and C. Bala Maniam, Member, IEDRC
}

\begin{abstract}
Structural changes in the economic transformation of Malaysia from an agricultural-based to an industrial-based economy after the 1970 s, were accompanied by an increase in the employment of women. This resulted in two predominant trends: firstly, an increase in dual earner families and secondly, the number of female university students surpassed males. However, due to the difficulty of juggling work and home, there has been a low female labour force participation of less than $\mathbf{4 8}$ percent in recent years. Trying to reconcile the issue of work and home, many economists and policy makers argue that workplace flexibility could be a major tool to retain talent and women in the labour market. This study uses evidence from a primary survey conducted among 14 organisations in the services industry in the central business hub in Malaysia. Self-administered questionnaires were answered by women on their perception of the relationship between flexible working arrangements and work life balance. We conclude that flexible working arrangements are preferred by women who are more educated and earning a higher income while the MANOVA analysis shows that flexible working arrangements have the potential to achieve work life balance.
\end{abstract}

Index Terms-Flexible working arrangements, Malaysian women, women and labour, workplace flexibility.

\section{INTRODUCTION}

Structural changes in the economic transformation of Malaysia from an agricultural-based to an industrial-based economy after the 1970s, were accompanied by an increase in the employment of women. This led to an increase in dual earner families in the country. On the other hand, although currently, Malaysian women make up more than 63 percent of students in tertiary educational institutions, less than half of them get absorbed into the workforce. Women's participation is as high as 65 percent in the 25-29 years age group but women often drop out of the workforce between the ages of 30 to 34 years due to household and family responsibilities [1]. For example, in the 2011 Labour Force Survey, 67 percent of women cited this as a reason for not seeking work [2]. As such, one of the objectives in The Tenth Malaysian Plan (2011 - 2015) is to increase the female labour force participation from the current 47.6 percent to 55 percent by 2015 .

Very few local companies in Malaysia have implemented flexible working arrangements (FWAs) while many

Manuscript received September 15, 2013; revised November 27, 2013. Geetha Subramaniam is with the Universiti Teknologi MARA, Malaysia (e-mail: geethamaniam@gmail.com).

John Overton is with the Development Studies at Victoria University of Wellington, New Zealand (email: john.overton@vuw.ac.nz).

Bala Maniam is with the Finance at the Sam Houston State University, USA (e-mail: GBA_BXM@shsu.edu). multinationals are very proud to highlight this workplace reform. The more common modes of FWAs in Malaysia are flexi-time, working from home, teleworking, permanent part-time and career break.

In an attempt to understand the low participation of women in the labour force in Malaysia, this paper seeks to examine the possible impact of workplace reforms on women's work life balance. This is investigated in the context of whether demographic and socio-economic factors have an effect on women's preference for FWAs at the workplace. This is further examined to see whether FWAs may have an impact on women's ability to juggle work and home to achieve work life balance. This paper finally concludes with discussions on family friendly policies and long-term measures which might have an effect on women's continued participation in the labour market.

\section{LITERATURE REVIEW}

\section{A. Women and the Labour Market}

Labour economists note that life cycles of female labour force participation (FLFP) rates vary more than males and differ between each country and are generally lower than men's at all stages of life. The "twin peak" phenomenon is observed in most countries and involves two periods of relatively high participation separated by a trough of lower rates in the central age groups. It is closely related to marriage and the family [3]. However, this phenomenon varies from country to country. Developed countries such as Japan and South Korea continue to have a double peak with a trough at ages 25-29 years, although this used to be at 20-24 years in 1990. The drop in FLFP rates has shifted to five years older and is not as sharp as before, "indicating later childbearing and childrearing as well as more women opting to continue working" [4]. However, this is not the case in some countries with relatively better pension and welfare systems.

According to the neo-classical model of labour supply, a primary factor affecting female LFP is female wages. Several studies have included wages in women's LFP equations. Aaberge et al., (2006) estimated significant positive effects of female wages on participation [5]. At low levels of economic development, women have high employment rates, primarily in agriculture or self-employment. As incomes rise, women leave the labour market, in part because of a preference that women not work outside the home in manual labour. But with greater development, and increases in women's human capital, white-collar opportunities become available and draw women back into the labour force.

The neo-classical theory of household choice and resource 
allocation is useful to explain the factors which influence the labour force participation of women. As the aim of all households is to maximise total utility by optimal allocation of resources, some factors will have a greater influence on women's decision to participate in paid work outside the home [6].

Women work due to economic and social reasons. As far back as the early 1980s, [7] clearly spells out that it was women from poor households in Malaysia who resorted to wage labour to supplement family income and in the course, were affected by wage differentials and gender discrimination. In this study, it was noted that poor female-headed households who have very little access to alternative childcare support systems have a high opportunity cost of working outside and this situation actually aggravated their dual-role burden.

In another study among college students, it was revealed that the majority of both men and women wish to participate in paid labour. This is an indication that the dual career family is likely to continue to be common in the future. However, this study showed that gendered expectations are still prevalent when it comes to the division of labour at home and work.

Paid work is now an integral part of women's lives. Not all women leave their jobs after childbirth [8]. Many debates and discussions on what causes women to exit the labour market point to family responsibilities either directly, due to dependent care or indirectly, due to employer policies [9], [10]. However, the fact remains that inflexibility at the workplace and inability to balance work; life and home are important factors why married women leave the labour force [11].

What influences a woman to leave an organisation after childbirth and not return has been a debate among organisational behaviourists and feminists and a few interesting points can be deliberated on. Theoretically, women who exit the labour force are making a rational decision anticipating the outcomes of alternative courses of action. The major assumptions in other economic theories is that people are rational when making major decisions, including quitting a job. Therefore, it is argued that women will not leave their paid jobs without a reasonable reason and a rational individual will choose the alternative that is likely to give them the greatest satisfaction.

Flexible Working Arrangements and Work Life Balance

The workplace of the future is one that will be driven by new energy and with vision as workplace flexibility and worker-friendly management strategies are becoming more important. FWAs are alternatives to the traditional "9-to-5" workday, the standard work week, or the traditional workplace.

Most of the reasons why female employees want FWAs centre on family responsibilities and work life balance [12]. Studies in the United Kingdom [13] and the United States [14] reveal that "spending time with family" was the most popular reason why women opted for FWA companies. According to [14] women face many constraints as they choose how they will balance work and family and what priority they will give to one over the other at particular times.

Employing the theory of work adjustment of Dawis,
England \& Lofquist, (1968), [16]'s study tried to examine the relationship between FWAs and quality of working life and employee productivity. The study showed the attitude difference in a FWA organisation explained in terms of stress associated with work arrivals being reduced and the possible increase in performance.

Studies have shown that an organisation which values its employees and recognises the importance of work life balance stands to win in terms of staff morale and commitment [17]. Employers should begin by revamping their recruitment policies to facilitate work life balance. FWAs, if used with quality practices at the workplace, can actually become the core of human resource management and lead to good work performance and higher productivity [18]. As argued by [19], FWAs are beneficial for both employers and employees and they also further described how highly it is valued by elderly parents, whose children work under flexible working arrangements.

Recent trend studies show that part-time work influences the ability of mothers with young children to balance work and family responsibilities. Mothers will be less likely to leave the labour market if more part-time jobs are available. This concept of part-time jobs and family friendly policies such as flexible working arrangements will enable more women to contribute to both, work and home. With more flexible work and part-time work, literature suggests that possible benefits for these young mothers will be better monitoring of the children and more quality time with the children [20].

In the neighboring country of Singapore, the Civil Service introduced flexitime as early as in 1970 with the main objective of easing traffic congestion during peak hours. But today, it is favourably received by staff as it enables better work life balance and the scheme has helped to better attract and retain valuable talents.

While FWAs have many benefits such as the ability to juggle work and home, men and women seek them for different reasons. For example, [21]'s study found that for senior management men, FWAs help them resolve commuting time, whereas for the women, FWAs are utilised more for family responsibilities and better quality of life.

Existing literature shows that women's participation in the labour market is affected to a certain extent by their workplace environment which affects their work life balance. Therefore, to retain women in paid labour, it might be pertinent to look at whether FWAs may reconcile work and home responsibilities, which is the main focus of this study.

\section{Methodology}

This paper seeks to examine the experience and perception of working women in flexible and fixed working organisations in the context of work life balance (WLB).

This study was conducted in the Klang Valley, the central business hub of Malaysia, using a quantitative method adapted from [22]. Based on the statistics from the Labour Force Survey Report Malaysia, 2011, six sub-groups in the services sector which had a substantial number of working women were identified. This was further narrowed down by using the Malaysian Employers Federation list, where 
organisations in the services sector which had FWAs and non-FWAs were identified.

Using the purposing sampling technique, a total of fourteen organisations which have FWAs were identified, and these organisations were sub-grouped further into Finance, Logistics, Petroleum Shared Services, Telecommunication, Educational Institutions and Small and Medium Professional companies. Random sampling was employed to reduce selection bias within each organisation, whereby respondents were selected at random by the Human Resource Manager of each organisation. A total of 500 self-administered questionnaires were distributed, 250 to FWA organisations and 250 to non-FWA organisations. The response rate was slightly lower for the non-FWA organisations compared to the response rate from FWA organisations. The total sample size was 396, which consisted of 57 percent respondents from FWA organisations and 43 percent respondents from non-FWA organisations.

The questionnaire consisted of 4 parts: Part A consisted of five items on the demographic profile of the respondents; Part B consisted of two items on the income level; Part C consisted of three items on family responsibilities; and Part D consisted of four questions on WLB where respondents indicated on a scale of 1 (Strongly Disagree) to 5 (Strongly Agree) on their perception on statements with regard to WLB. Data was analysed using the SPSS 20 software. Cross tabulations and the MANOVA analysis were used to analyse the findings.

\section{FINDINGS}

A majority of the respondents $(86 \%)$ in this study were interested in FWAs at the workplace. The results indicate that socio-economic status affects female employees' desire to take up FWAs at the workplace. Women holding a degree, earning an income above RM7000 (1USD = RM3.10), and in the higher occupational status were the ones who were more interested in FWAs.

To examine the first objective of whether demographic and socio-economic factors have an effect on women's preference for flexible working arrangements at the workplace, cross tabulations were done. Table I shows the summary of the cross tabulations and the significance at 10 percent. In terms of demographic profile, FWAs were preferred among the Chinese ethnicity, women who were in the 30-39 years age group and among married women. However, none of these demographic factors were statistically significant. In terms of socio-economic factors, it was found that women who were at the management level, earning an income above RM7000 and having a university degree, were more interested in FWAs at the workplace. And these findings were statistically significant at 10 percent.

As for the second objective, whether FWAs may have an impact on women's ability to juggle work and home to achieve WLB, a multivariate analysis of variance was done. Based on focus group discussion with women's groups, and women employees, items which measure work life balance were included in the questionnaire. There were four items for work life balance. Respondents indicated on a scale of 1 (Strongly Disagree) to 5 (Strongly Agree) their perception on statements with regards to the three selected indicators.

In this study, the independent variable "Working Arrangements" was being tested against the dependent variable "Work Life Balance" to determine whether working in organisations which have FWAs have an effect on WLB.

For the concept of "Work Life Balance", an exploratory factor analysis, a dimension reduction technique, was performed using a varimax rotation [23]. Based on the eigenvalues, only one factor with value more than 1 was retained in the construct WLB. In this analysis, the KMO value for WLB was 0.6 , which is considered to be acceptable. A single factor was extracted that explained more than 63 percent of the variability in the data. The norm is that at least $50 \%$ of the total variance must be explained by the factor. The factor loading, KMO values and explained variation are shown in Table II.

TABLE I: SUMMARY OF CROSS TABULATION RESULTS OF DEMOGRAPHIC AND SOCIO-ECONOMIC FACTORS

\begin{tabular}{|c|c|c|c|c|}
\hline Variable & Sub Group & $\begin{array}{c}\text { Interested } \\
\text { in FWAs } \\
n / N\end{array}$ & $\%$ & $p$-value \\
\hline \multirow[t]{3}{*}{ Ethnicity } & Malays & $183 / 215$ & 85 & 0.744 \\
\hline & Chinese & $82 / 92$ & 89 & \\
\hline & Indians & $66 / 78$ & 85 & \\
\hline \multirow[t]{4}{*}{ Age } & $20-29$ & $143 / 167$ & 86 & 0.846 \\
\hline & $30-39$ & $136 / 155$ & 87 & \\
\hline & $40-49$ & $44 / 52$ & 85 & \\
\hline & 50 and above & $18 / 22$ & 82 & \\
\hline \multirow[t]{2}{*}{ Marital Status } & Married & $216 / 250$ & 86 & 0.470 \\
\hline & Single & $125 / 146$ & 85 & \\
\hline \multirow{5}{*}{$\begin{array}{l}\text { Occupational } \\
\text { Status }\end{array}$} & Clerical Level & $64 / 92$ & 70 & $0.000 *$ \\
\hline & Technicians & $17 / 18$ & 94 & \\
\hline & $\begin{array}{l}\text { Officers/ } \\
\text { Executives }\end{array}$ & $163 / 182$ & 90 & \\
\hline & Lecturers & $49 / 55$ & 89 & \\
\hline & $\begin{array}{l}\text { Management } \\
\text { Level }\end{array}$ & $46 / 47$ & 98 & \\
\hline \multirow[t]{6}{*}{$\begin{array}{l}\text { Personal } \\
\text { Income }\end{array}$} & $\begin{array}{l}\text { RM1000- } \\
\text { RM2000 }\end{array}$ & $112 / 141$ & 79 & $0.012 *$ \\
\hline & $\begin{array}{l}\text { RM2001- } \\
\text { RM3000 }\end{array}$ & $77 / 91$ & 85 & \\
\hline & $\begin{array}{l}\text { RM3000- } \\
\text { RM4000 }\end{array}$ & $36 / 42$ & 86 & \\
\hline & $\begin{array}{l}\text { RM4000- } \\
\text { RM5000 }\end{array}$ & $19 / 20$ & 95 & \\
\hline & $\begin{array}{l}\text { RM5000- } \\
\text { RM7000 }\end{array}$ & $43 / 45$ & 96 & \\
\hline & Above RM7000 & $41 / 42$ & 98 & \\
\hline \multirow[t]{5}{*}{$\begin{array}{l}\text { Educational } \\
\text { Level }\end{array}$} & $\begin{array}{l}\text { SPM/ "O" } \\
\text { Levels }\end{array}$ & $60 / 81$ & 74 & $0.000 *$ \\
\hline & $\begin{array}{l}\text { STPM/ "A" } \\
\text { Levels }\end{array}$ & $20 / 24$ & 83 & \\
\hline & Diploma & $71 / 89$ & 80 & \\
\hline & Degree & $145 / 153$ & 95 & \\
\hline & Post-Graduate & $45 / 49$ & 92 & \\
\hline
\end{tabular}

* Significant at 5 percent

TABLE II: SUMMARY RESULTS FROM FACTOR ANALYSIS

\begin{tabular}{lccc}
\hline Construct & No of Items & KMO & $\begin{array}{c}\text { Explained } \\
\text { variation }\end{array}$ \\
\hline WLB & 4 & 0.6 & $63 \%$ \\
\hline \hline
\end{tabular}

Using the MANOVA test, it was found that the mean for work life balance was $p=0.025$, which shows significant difference between women in the FWA organisations and 
non-FWA organisations. The MANOVA test showed that working arrangements had an effect on women's well-being in terms of work life balance.

\section{DISCUSSION AND CONCLUSION}

Evidence from this analysis shows that FWAs have a positive effect on WLB which might have a predominant effect on women's decision to work in paid labour. Three main conclusions which can be drawn from this study are:

Firstly, quantitative analysis reveals that socio-economic factors have an effect on women's uptake of FWAs in the workplace. Higher educated women who are holding university degrees, and earning a higher income with higher occupational status are more interested in FWAs at the workplace compared to women who do not possess higher education.

In a knowledge economy, human capital is given paramount importance as the knowledge worker's competencies are a key component of value in realising organisational goals. This in turn relates to the impending issue of women leaving their careers to care for their families as a serious economic issue, as these women are mostly young and educated women in their mid-thirties. This conforms to micro level studies done recently [24].

Secondly, findings show that women perceive that the best benefit of FWAs is a better relationship among family, children and siblings. This arises from the better WLB achieved among women who use FWAs.

This conforms to studies of teleworkers in Singapore by [25] who also found that more family time and less commuting time were the main reasons women prefer flexible time and flexibility in location. This is an indication that FWAs offer female employees time flexibility, less commuting stress, more autonomy and better job satisfaction.

Finally, in terms of demographic and socio economic factors, even though FWAs do not statistically have any significant effect on WLB, it was the women in the 30-39 years age group who were having caring responsibilities who preferred FWAs.

This is due to the patriarchal values which still persist in the Malaysian culture where the women are responsible for household chores and caring responsibilities as well.

Although this study has several notable contributions which are relevant to FWAs, WLB and low participation of women in the labour market in Malaysia, several issues can be investigated further. Firstly, the sample size could be increased. Secondly, this study focused on the services sector, further studies could be done to examine primary and secondary sectors.

\section{POLICY IMPLICATIONS AND RECOMMENDATIONS}

What does this all mean to Malaysian society in general and Malaysian women specifically?

Many working women have a serious issue with WLB. This research findings reveal that the two main reasons are: firstly, the inability to juggle work and home well and secondly, the patriarchal views that home is the responsibility of the women, which still very much exists.

Some implications of this study are as follows:

Firstly, there is a pragmatic need to align labour market policies with prevailing and future family structures. In this sense, the government has to provide an enabling environment in a more institutionalised way for childcare facilities which are more affordable and reliable.

Secondly, awareness needs to be created as to how WLB can be achieved by men and women who work in the paid labour market.

Thirdly, and most importantly, there needs to be attitudinal shifts in the society as family-friendly policies alone are not enough to ensure WLB. The stereotype of a woman as a homemaker should be challenged and society should move towards a new level of thinking where caring and sharing are shared responsibilities. Though this has to start from the home, employers also need to take a step forward by providing more family-friendly policies which not only benefit women but also the family.

As the former US Secretary of State announced, "So often, it takes only one woman to make a difference. If you empower that woman with information, training, or a microloan, she can lift up her entire family and contribute to the success of her community. Multiply that one woman's impact by a hundred or a thousand, and perhaps a million lives can change".

As for policy recommendations, firstly, FWAs such as flexi time, working from home, permanent part-time and teleworking may allow women with caring responsibilities to reconcile work and family responsibilities. Secondly, though FWAs are very beneficial to women and society, they come with some limitations as well. Hence, it is not a simple concept which can be offered to all but it is a policy which needs to be configured well and offered on a case-to-case basis. Last but not least, the challenge of a successful implementation of FWAs lies collectively on employers, policymakers, and society in general.

As Malaysia moves towards achieving an industrialised nation status by 2020, many policies set to bring women into the labour force show the government's increasing concern on this issue. Even though patriarchal concerns in the home front need to be addressed, the equally significant issue of a paradigm shift in the working environment to facilitate women's juggling of paid and unpaid labour, needs to be delved in further.

\section{REFERENCES}

[1] Ministry of Women, Family and Community Development, Statistics on Women, Family and Community, 2011, 2012.

[2] Department of Statistics, Labour Force Survey Report, 2011.

[3] J. D. Durand, "The labor force in economic development," $A$ Comparison of International Census, 1946-1966, Princeton: Princeton University Press, 1975.

[4] United Nations, The World's Women 2010 Trends and Statistics, pp. 80, 2010 .

[5] R. Aaberge, E. Fjaerli, A. Langorgen, and M. Mogstad, "Comparability of income data across households/individuals and over time," in Eurostat (Ed.), Comparative EU statistics on Income and Living Conditions: Issues and Challenges, in Proc. the EU-SILC conference, pp. 57-75, 2006.

[6] G. Borjas, Labor Economics, Fifth Edition, 2009. 
[7] A. Jamilah, Women, Development and Poverty: Globalised Issues and Empirical Findings Relevant to Studying Poor Women in Malaysia, Petaling Jaya: Pelanduk Publications, 1994.

[8] E. Kaplan and S. G. Cherlyn, "Factors influencing women's decision to leave an organization following childbirth," Employee Responsibilities and Rights Journal, vol. 6, no. 1, pp. 45-54, 1993.

[9] P. Voydanoff, "Work role characteristics, family structure demands, and work/family conflict," Journal of Marriage and Family, vol. 50, no. 3, pp.749-761, 1988.

[10] G. Subramaniam, S. Mohamad, and D. P. Selvaratnam, "Why do some women leave the labour force? A micro perspective from Malaysia," Economic Bulletin, vol. 11, 2010.

[11] K. Amarjit, Costed Not Valued: Women Workers In Industrialising Asia, New York, Palgrave Macmillan, 2004.

[12] J. M. Liechty and E. A. Anderson, "Flexible workplace policies: lessons from the federal alternative work schedules act," Family Relations, vol. 56, pp. 304-317, 2007.

[13] G. A. Cole, "Flexibility and the workplace: The battle to control working time," Managerial Law, vol. 48, no. 6, pp. 536-540, 2006.

[14] J. L. Hotchkiss, "Changes in behavioral and characteristic determination of female labor force participation, 1975-2005," Economic Review, vol. 17, no. 1, pp. 106-138, 2006.

[15] S. Borjalilou, S. Nazemi, S. Mortazavi, and H. Rahmanseresht, "Reflection of post-feminist viewpoints on female related issues in organizations," Interdisciplinary Journal of Contemporary Research in Business, vol. 4, iss. 10, pp. 683, Feb. 2013.

[16] J. L. Pierce and J. W. Newstrom, "Toward a conceptual clarification of employee responses to flexible working hours: A work adjustment approach," Journal of Management, vol. 6, no. 2, pp. 117-134, 1980.

[17] L. Liddicoat, "Stakeholder perceptions of family-friendly workplaces: An examination of six New Zealand Organisations," in Asia Pacific Journal of Human Resources, vol. 41, pp. 354, 2003.

[18] H. S. C. Irene and C. K. H. Irene, "The effect of altenative work schedules on employee performance," International Journal of Employment Studies, vol. 14, no. 1, pp. 105-129, 2006.

[19] J. M. Liechty and E. A. Anderson, "Flexible workplace policies: lessons from the federal alternative work schedules act," Family Relations, vol. 56, pp. 304-317, 2007.
[20] B. Olmstead and S. Smith, "Creating a flexible workplace-how to select \& manage alternative work options, New York," American Management Association, 1994.

[21] D. Eileen and M. M. Eamonn, "Work/life balance: senior management champions or laggards?" Women in Management Review, vol. 20, no. 4, pp. 262-278, 2005

[22] E. D. Almer, J. R. Cohen, and L. E. Single, "Factors affecting the choice to participate in flexible work arrangements," Journal of Auditing, vol. 22, no. 1, pp. 69-91, March 2007.

[23] J. F. Hair, W. C. Black, B. J. Babin, and R. E. Anderson, Multivariate Data Analysis A Global Perspective, Seventh Edition, Pearson Prentice Hall, New Jersey, USA, 2010.

[24] G. Subramaniam, M. G. Iyer, S. Mohamed, and N. Nor, "Children and women's decision not to work -a study in Klang Valle," Malaysian Journal of Consumer and Family Economics, vol. 13, pp. 18-27, 2010,

[25] V. K. G. Lim, T. S. H. Teo, and S. K. B. See, "Perceived job image among police officers in singapore; factorial dimensions and differential effects," The Journal of Social Psychology, vol. 140, no. 6, pp. $740-750,2000$.

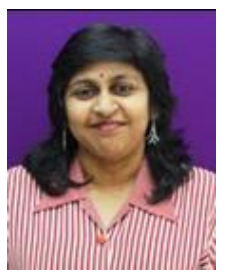

Geetha Subramaniam is a senior lecturer on Economics at the Faculty of Business Management, Universiti Teknologi MARA, Shah Alam, Malaysia. She obtained her Ph.D. from Victoria University of Wellington, New Zealand in the area of Development and Economics. Her research interests include labour economics, women issues and development economics.

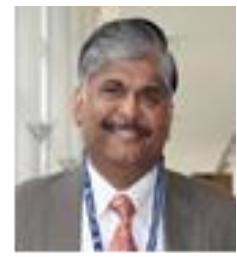

Balasundram Maniam is a minnie stevens piper professor and Texas State University system regents' professor of Finance at Sam Houston State University, USA. He obtained his Ph.D. in Finance from University of Mississippi. He has published in over 150 peer-reviewed journals and presented in over 250 international and national conferences. He was also the recipient of the Excellence in Research and Excellence in Teaching awards at Sam Houston State University in 2003 and 2008 respectively. 